\title{
Agility Factors' Analyses Framework in Project-Oriented Organizations through a Sustainability Approach in Large Projects Case Study: Isfahan Municipality
}

\author{
Ahmadreza Tahanian, ${ }^{1}$ Hasan Haleh $\left(\mathbb{D}^{2}{ }^{2}\right.$ Farhad Etebari, ${ }^{1}$ and Behnam Vahdani1 \\ ${ }^{1}$ Department of Industrial Engineering, Faculty of Industrial and Mechanical Engineering, Qazvin Branch, \\ Islamic Azad University, Qazvin, Iran \\ ${ }^{2}$ Industrial Engineering Department, Golpayegan University of Technology, Golpayegan, Iran
}

Correspondence should be addressed to Hasan Haleh; hasanhaleh40@gmail.com

Received 27 June 2021; Revised 1 August 2021; Accepted 4 August 2021; Published 17 September 2021

Academic Editor: Michela Gelfusa

Copyright (C) 2021 Ahmadreza Tahanian et al. This is an open access article distributed under the Creative Commons Attribution License, which permits unrestricted use, distribution, and reproduction in any medium, provided the original work is properly cited.

\begin{abstract}
In recent years, the project management concept is coupled with sustainable development. In terms of profitability and adapting to environmental changes, generating value for the customer and responding to market needs is a challenging issue. To gain profit and success, a project should adhere to agility factors. With respect to the importance of project execution success, corresponding to the sustainability dimensions and by developing agility parameters, this study provides a framework for clustering and analyzing "large projects" based on agility factors in project-oriented organizations through a sustainability approach and by applying Quality Function Deployment. To this end, critical factors of project success and then agility factors of the projectoriented organizations have been identified. Thereafter, the importance of these two major components has been measured by executive managers in Isfahan Municipality and academic experts. Afterward, the agility factors' weights have been calculated based on extracted sustainability factors' weights, which have been gained according to the project's critical success factors and by applying quality function deployment. By determining the agility factors' clusters in the project-oriented organizations and calculating their importance weights, the first cluster that contains project communication management, organizational culture, and contracts management gains the maximum weight of importance.
\end{abstract}

\section{Introduction}

In today's business world, in many projects, considering the very high level of uncertainty in all aspects of the activities, priorities, and latencies, activity connections, and also resources correlation, applying the traditional techniques and instruments in project planning is a hard task. In such cases, mere project planning improvement would not yield satisfactory output. For any type of project, an agile model can promote quality and productivity in a specific time and resource framework [1]. The purpose of organizational agility $(\mathrm{OA})$ as a major contributive dynamic ability is for realizing the environmental changes and respond effectively and efficiently to the changes therein. Being engulfed with environmental, highly dynamic, complex, and uncertain changes, organizations face serious threats as to their survival in a highly competitive market. Such business atmosphere being equipped with mechanisms which allow the organizations to respond appropriately to the identified changes will directly be connected with better performance in order to taking the new opportunities and resources in a competitive world. Thus, agility is a concern for the survival and success of the organization [2]. Applying the principles of agility to the project as an interim organization is a necessity to deal with environmental uncertainties. Agility is mostly concentrated on the project implementation phase. This approach focuses on the accuracy of planning with respect to the details of planning, better risk management, and more customer affair on its agenda [3]. 
Innovative and sophisticated technologies have introduced dramatic changes in industrial products and social services [4]. Project management is obligated to manage both the simple and complex activities through modern approaches that are more efficient than the traditional approaches. A project manager seeks to complete the project within time, cost, and resources framework and by generating value for the client [5]. The project management system faces serious and expanding challenges as to value generation response to changes and profitability in business environment. To overcome this challenge, the project needs performance agility. In this century, achieving sustainable development is a blanket and essential challenge for all organizations. Sustainability is a concept on which the researchers and entrepreneurs concern in order to improve and integrate it with the field of project management at different social and business levels [6]. Sustainability is defined as an innate potential through which the long-term, resource-related risks, fluctuations in energy costs, debts, product costs, and pollution are reduced and the waste management is improved. The equilibrium among economic development, supervising environmental issues, and social justice is another definition of sustainability [7], provided that the importance weights of all three fields of economy, environmental conformity, and social balance are considered as equal [8]. The objectives of promoting economic growth, social health, and rational natural resource utilization cannot be actualized without considering the effects of the mentioned components. As to organizational success, sustainability would provide balance and harmony among these three components. This concept is named triple bottom lines (TBL) and offers different values and perspectives to measure the success of organizations in the three areas of economics, society and the environment. The three main components of sustainability are population, world, and profits. Profit is directly related to economics, population contains society and the organizational environment, and the other component modifies the environmental consequences. The first component consists of the economic environment, and the second is the environmental effects caused by the organization's activities [9]. The increase in the projects' success depends on the managers' improvement in approaches towards the project objectives. Rational decisions drawn by management are highly contributive in project management and the outcomes therein [10]. For this purpose, project management, the core operations of a business, is not separated from sustainability concept [11]; consequently, the field of project management requires project managers to be fully responsible in project sustainability (Silvius and Brink, 2012). The products, services, technologies, projects, and organizations each on its own constitute a sustainable system. According to the project complexity, to deliver the project results subject to sustainability conditions, the necessary instruments and techniques must be properly coordinated [12].

Dynamism in today's economy requires projects that would introduce major changes in people's daily conducts. Due to the current global crisis and gradual resource depletion, as we go forward, project managers are obligated to develop new and innovative perspectives on sustainability and devise measures to achieve the appropriate levels therein. As to time, the nature of the project is periodic and to status is discrete, while the nature of sustainability is unified. To achieve sustainable development, the project activities must follow economically transparent, socially acceptable, and environmentally safe pattern [13]. Project managers often try to improve the issues related to measurement, success, and factors influencing the project performance and seek to improve them [13]. In project management perspective, the critical success factors consist of features, circumstances, and variables, the effect of which on project success are oriented towards sustainability [14].

A brief review of the related literature, in the context of modern business, would reveal the importance of agility, as a key approach as to adapting to the changes in the business world, responding to the customer and generating value therein, in project-oriented organization. Expanding sustainability, that is, observing its principles with respect to resource utility, which should correspond with the credible sources of project management, is essential. Depending on the features, a large project is a type of project that typically has a longer duration (it might be run for more than six months), larger teams of staffs (include more than 25-30 members and even may require the support staff), greater budget and resource allocation, and more tasks complexity, including many tasks having to be done concurrently. A project-oriented organization that manages and executes large projects can be a complex network with high rate of interactions. Hence, the complexity of such systems leads the organization to be agile while they are following the sustainability principles and manages the projects on the basis of critical success factors of project management.

In this study, a framework is proposed for analyzing agility factors in project-oriented organizations with a sustainability approach in big projects by applying quality function deployment (QFD). Identifying agility factors in project-oriented organizations based on the main project success and sustainability factors is a major step in evaluating the project, based on the agility and sustainability approach, which in turn would promote adaptation to the changes in business environment and customer demands. Determining the factors' weight and their clustering in determining the important clusters, which would contribute in planning and goal setting, is essential. This can be accomplished by applying the principles of agility and sustainability components.

This article is organized as follows: the literature is reviewed in Section 2; the project management is explained in Section 3; agility in project-oriented organization is introduced in Section 3.2; the sustainability is discussed in Section 3.3; QFD is applied in Section 3.4; clustering is analyzed in Section 3.5; the research method is detailed in Section 4, the framework is implemented in the subject organization in Section 5, and the article is concluded in Section 6.

\section{Literature Review}

To review the research literature, the connected researches have been found based on the keywords and the journals 
with the related issues. The select studies run on the main factors of project success are tabulated in Table 1, the select studies run on sustainability are tabulated in Table 2 , and the select studies run on organizational agility are tabulated in Table 3.

What is deduced from reviewing the related articles is that in today's competitive and changing business world, customer satisfaction is accredited to the organization credibility, quality and speed in response, and agility in project performance. Project-oriented organizations are fully aware of the need to incorporate agility dimensions in project management if adaptation to changes in the environment and response-specified time, cost, and resources are sought. Organizations are obligated to assess the resource planning and the effects of a project as to its economics and profitability, with respect to social dimension next to its effects in environmental sense to correspond with sustainability. The different aspects of organization and management approaches as to resource allocation and planning for project control, resource protection, environmental effects, economic performance, and social effects of the project are subject to direct effect of sustainability.

Identifying the agility indices and dimensions in projectoriented organizations, based on accurate infrastructure according to the critical success factors of project and the dimensions of sustainability in three areas of economic, social and environmental therein, has been somewhat neglected. In this context, while evaluating the project based on the mentioned factors, the project manager should strengthen the weak indices and generate value, respond to the customer and meet his/her satisfaction, if achieving sustainability, profitability, credibility and social prestige and effects are sought. This in turn would allow successful performance to assure environmental and social sustainability. In all these efforts, though the project was delivered successfully, still the agility aspect is missing in the run studies.

\section{Theoretical Background}

3.1. Project Management. A project consists of human and nonhuman resources, in a temporary organizational framework with the objective to accomplish a specific task [5]. Organizations, today, perceive a project as a manner of organizing tasks. In most industrial, commercial, and governmental organizations, project management is perceived as an instrument to accomplish objectives [30]. The project assists the organization to define and select a set of activities that would generate positive results therein. This phenomenon can be applied in economic, marketing, or technical areas. The project manager is obligated to manage the project through a set of instruments and methods without disturbing the regular routine operations of the organization. Project management activities consist of defining task requirements, planning and scheduling task implementation, allocation progress, monitoring, and keep project planning online. As to project delivery, the responsibility of the project manager is to have met all budget and desired operational and quality standards [31]. Project management can be considered as a temporary effort in separate fields of activities with a specific beginning and end time. Given the existing global economic status, projects must be managed and controlled in a periodical manner. Time, cost, and objective achievement level are considered as the indices of success or failure for organizations that should be supported per project beginning from the structure to the budget. Supervision and control in the implementation phase are also necessities [16]. Project management as an effective controlling instrument is expressed in multiactivity endeavors [32].

3.2. Agility in Project-Oriented Organizations. Today, organizations face varying, dynamic, complex, and uncertain circumstances in these highly competitive markets that pose a threat to organizations [2]. The innovative and sophisticated technologies have introduced dramatic changes in industrial products and social services [3]. Business and management models are essential to support Industry adoption and foster sustainable value creation and competitiveness [4]. The need for an efficient management strategy is evident [32]. Organizational agility enables an organization to understand the environmental changes and provide an appropriate response as to adapting it as a management mechanism [2]. In a sense, these environmental features are the challenges confronting project management [33]. The principles of project management based on traditional techniques are based on regular planning and control practices. Developing an integrated network, consisting of customers, suppliers, supervisors, authorities, and political institutions and competitors is a proper manner of responding to environmental changes, something impossible in traditional project management format.

3.3. Sustainability in Project-Oriented Organizations. The ongoing major changes at global scale have made sustainable development an important strategic measure. Sustainable development seeks to protect, develop, and balance economic, social, and environmental objectives to the available resources to assure the comfort and convenience of the generations to come. The correlation between these objectives and resources is high and important. Today, next to economic values, countries must consider the social benefits and environmental consequences as well. Climate change threatens the future significantly to a certain extent. The natural resources are depleting recklessly, that is, accessing them will be difficult if not impossible for the next generation [34]. Nowadays, organizations define their activities and business as projects and seek to improve their success. Drawing managerial decisions are contributive in project management and its outcomes [10]. Sustainable development addresses humanity's aspiration for a better life while observing the limitations imposed by nature [35]. Dynamism in today's global economy is based on the available projects with the objective to make major changes in people's lives. The current global crisis and extending resource depletion force project managers to develop innovative perspectives on sustainability and assure its continuity. The nature of any project is temporary and discrete, accomplishable through different techniques and methods. Sustainability is not an isolated concept, and it is achieved by 
TABLE 1: Review on the related literature of critical success factors.

\begin{tabular}{|c|c|c|c|c|c|}
\hline Row & Authors & Year & Objective & $\begin{array}{l}\text { Method and } \\
\text { tools }\end{array}$ & Description \\
\hline 1 & $\begin{array}{l}\text { Ahmadabadi, and } \\
\text { Heravi [15] }\end{array}$ & 2019 & $\begin{array}{l}\text { Assessing the CSF in state/private sector } \\
\text { joint ventures, the national highways }\end{array}$ & RLS & $\begin{array}{c}\text { All operations at all stages are supervised, and } \\
\text { the project is evaluated against critical } \\
\text { situations as to its success }\end{array}$ \\
\hline 2 & $\begin{array}{l}\text { De melo moura } \\
{[16]}\end{array}$ & 2016 & $\begin{array}{l}\text { Identifying the main factors as to support } \\
\text { information system's projects }\end{array}$ & - & $\begin{array}{l}\text { PMCSFS are contributive in optimum } \\
\text { performance in information systems }\end{array}$ \\
\hline 3 & Orouji [17] & 2016 & A review run on articles on PMCSFS & - & $\begin{array}{l}\text { Assessing the articles published from } 1978 \text { to } \\
2015 \text { as to their CSF vs. failure in 6-sigma } \\
\text { projects }\end{array}$ \\
\hline 4 & $\begin{array}{l}\text { Costantino et al } \\
{[18]}\end{array}$ & 2015 & $\begin{array}{l}\text { Selecting the projects for forming a } \\
\text { portfolio by applying ANN according to } \\
\text { CSF }\end{array}$ & $\begin{array}{l}\text { DSS } \\
\text { ANN }\end{array}$ & $\begin{array}{l}\text { To design, develop, and test the decision- } \\
\text { making support systems for predicting project } \\
\text { functionality and applying ANN to form CSF } \\
\text { groups according to risk rate }\end{array}$ \\
\hline 5 & $\begin{array}{c}\text { Alias et al } 2014 \\
\text { [19] }\end{array}$ & 2014 & $\begin{array}{l}\text { Determining the CSFs in project } \\
\text { management in a comprehensive } \\
\text { framework }\end{array}$ & $\begin{array}{l}\text { Statistical } \\
\text { tests }\end{array}$ & $\begin{array}{l}\text { The connection rate between CSF and project } \\
\text { functionality is measured and a } \\
\text { comprehensive method consisting of project } \\
\text { management, methods, human factor, external } \\
\text { issues, and project-related features are } \\
\text { presented }\end{array}$ \\
\hline 6 & $\begin{array}{l}\text { Abdulrahman et al } \\
{[5]}\end{array}$ & 2014 & $\begin{array}{l}\text { Determining the essential features in } \\
\text { project success and the techniques that } \\
\text { lead to project management success }\end{array}$ & - & $\begin{array}{l}\text { Project management theory, project systems, } \\
\text { and the CSFs are addressed }\end{array}$ \\
\hline 7 & $\begin{array}{l}\text { Thi and swierczek } \\
{[20]}\end{array}$ & 2010 & $\begin{array}{l}\text { Measuring project success based on CSFs } \\
\text { in project management and run case } \\
\text { studies in Vietnam }\end{array}$ & $\begin{array}{l}\text { Regression } \\
\text { analysis }\end{array}$ & $\begin{array}{l}\text { Completing the project life cycle that is } \\
\text { directly related to positive relations and } \\
\text { success. In the project execution, the external } \\
\text { consistency affects and organization support is } \\
\text { compensated for }\end{array}$ \\
\hline 8 & Naoum et al [19] & 2004 & $\begin{array}{l}\text { Identifying the critical and noncritical } \\
\text { factors affecting the project success in big } \\
\text { construction projects }\end{array}$ & - & $\begin{array}{l}\text { A management led by project and execution } \\
\text { management }\end{array}$ \\
\hline
\end{tabular}

applying project activities run in continuous and transparent economic, social, and environmental context [13]. To deliver a project yield subject to sustainability, the required instruments and techniques should be in accordance with the complexity of the project [36]. Sustainability theme is involved in the integration of the three aspects: economic, social, and environmental aspects, which extends in project management and project delivery, followed by enhancing the project system and the management therein [37].

3.4. Quality Function Deployment. Quality function deployment is one of the qualitative tools contributive in providing services and producing products that would meet consumers' requirements. As one of the new methods in engineering, quality function deployment begins from running studies on market and identifying consumer services while identifying users' demands and seeks to apply them in the design process. The basic insight of this method is to convert the qualitative features into technical features, production processes, and requirements, by applying four matrices, in which the house of quality is the most important part. This matrix has a number of numerical inputs, which after the qualitative identification of the features, statistical methods will be applied to calculate the relative importance of the features on the basis of the consumers' opinions and experienced people ideas [38]. Hence, QFD promotes the systematic translation of customer needs and requirements into design requirements and evaluates alternatives and their impacts [39].

3.5. Clustering. Clustering and classification are among the most efficient methods in data analysis. Extracting the patterns through grouping individuals and variables is one of the main objectives consisting of many methods and patterns applicable in different scientific fields because human beings when encountering complex issues instinctively seek to compare and divide the given data as different groups. These methods are applied in different scientific fields like medicine, biology, management, planning, data mining, information discovery, and new structure in speech and images and environmental and natural sciences $[40,41]$.

Massive data, next to being beneficial for organizations and individuals, are problematic when it comes to their analysis. Data mining techniques is a solution in extracting beneficial information and correlations therein. Clustering, with its different methods, is one of the powerful instruments to forces these analyses. Identifying clusters or areas with dense population in a multidimensional data set through different techniques and algorithms is one of the 
TABLE 2: Review on the related literature of sustainability factors.

\begin{tabular}{|c|c|c|c|c|c|}
\hline Row & Authors & Year & Objective & $\begin{array}{l}\text { Method and } \\
\text { tools }\end{array}$ & Description \\
\hline 1 & $\begin{array}{l}\text { Mavi, and Standing } \\
{[21]}\end{array}$ & 2018 & $\begin{array}{l}\text { Introducing project management's CSFs } \\
\text { in the five project, project management, } \\
\text { organization external environment, and } \\
\text { sustainability }\end{array}$ & $\begin{array}{l}\text { Fuzzy } \\
\text { DEMATE L- } \\
\text { ANP }\end{array}$ & $\begin{array}{l}\text { By applying fuzzy DEMATEL } \\
\text { organization and sustainability } \\
\text { environment are recognized as the } \\
\text { causes, and project management is } \\
\text { recognized as the effect and ANP is also } \\
\text { applied for weighing the subcriterion }\end{array}$ \\
\hline 2 & $\begin{array}{l}\text { Dobrovolskienè, and } \\
\text { Tamošiūniené [22] }\end{array}$ & 2016 & $\begin{array}{l}\text { Measuring construction industry } \\
\text { projects sustainability in Lithuania }\end{array}$ & MCDM & $\begin{array}{c}\text { The case study results show that from } \\
\text { industrial experts' point of view, } 15 \\
\text { indicators are more important than the } \\
\text { whole }\end{array}$ \\
\hline 3 & $\begin{array}{l}\text { Martens and } \\
\text { Carvalho [23] }\end{array}$ & 2017 & $\begin{array}{l}\text { Assessing key factors in project } \\
\text { management in all its dimensions }\end{array}$ & $\begin{array}{l}\text { Factorial } \\
\text { exploration } \\
\text { analysis }\end{array}$ & $\begin{array}{l}\text { Results show that innovative and } \\
\text { sustainable business model, stockholders } \\
\text { management, economy and competitive } \\
\text { management, and finally, environmental } \\
\text { policies and resources storage are } \\
\text { paramount factors }\end{array}$ \\
\hline 4 & Daneshpour [24] & 2015 & $\begin{array}{l}\text { Assessing the management and the } \\
\text { aspects of combining project } \\
\text { management and sustainability }\end{array}$ & - & $\begin{array}{l}\text { Organizations' awareness to know the } \\
\text { value of sustainability and to achieve } \\
\text { sustainability dimensions in practice }\end{array}$ \\
\hline 5 & Amiril et al [25] & 2014 & $\begin{array}{l}\text { Evaluating sustainability factors and } \\
\text { project performance in transportation } \\
\text { infrastructure }\end{array}$ & - & $\begin{array}{c}\text { Sustainability factors and project } \\
\text { performance can be fit in environmental, } \\
\text { economic, resource utility, and project } \\
\text { management categories }\end{array}$ \\
\hline 6 & $\begin{array}{l}\text { Silvius and schipper } \\
{[26]}\end{array}$ & 2014 & $\begin{array}{l}\text { Assessing sustainability as one of the } \\
\text { project management competencies and } \\
\text { analyzing the gaps therein among the } \\
\text { present project managers }\end{array}$ & - & $\begin{array}{l}\text { By identifying this gap, procedures are } \\
\text { proposed to minimize it in addition to } \\
\text { introduce new measures and standards in } \\
\text { this context as to organization } \\
\text { sustainability }\end{array}$ \\
\hline
\end{tabular}

TABLE 3: Review on the related literature of agility factors in project-oriented organizations.

\begin{tabular}{|c|c|c|c|c|c|}
\hline Row & Authors & $\begin{array}{c}\text { Publication } \\
\text { year }\end{array}$ & Objective & $\begin{array}{l}\text { Method and } \\
\text { instrument }\end{array}$ & Description \\
\hline 1 & Pocter et al [27] & 2019 & $\begin{array}{l}\text { Providing a pattern for } \\
\text { competition scram network in } \\
\text { agile project management }\end{array}$ & - & $\begin{array}{c}\text { Integrating agility methods and principles in } \\
\text { multidisciplinary cooperation require high } \\
\text { flexibility and training patterns through } \\
\text { implementation }\end{array}$ \\
\hline 2 & $\begin{array}{l}\text { Fernandez and } \\
\text { Fernandez [28] }\end{array}$ & 2018 & $\begin{array}{l}\text { A review run on articles focused on } \\
\text { agile project management and } \\
\text { project success therein }\end{array}$ & - & $\begin{array}{c}\text { The traditional and modern project } \\
\text { management steps are compared in this } \\
\text { context. It is found that APM is effective in } \\
\text { project success }\end{array}$ \\
\hline 3 & Chen et al [29] & 2018 & $\begin{array}{c}\text { Assessing the agility and } \\
\text { sustainability concepts as } \\
\text { contradicting or complementary } \\
\text { concepts }\end{array}$ & - & $\begin{array}{l}\text { Generating value for customer and adopt it } \\
\text { with the environments changes next to } \\
\text { seeking sustainability in both the contexts }\end{array}$ \\
\hline
\end{tabular}

major issues in multidimensional data analysis. Finding the proper clustering algorithm or/and the most optimal clusters, in a reasonable time, is one of the major challenges in this field [42].

Clustering consists of grouping similar samples into one data mass. The essential point here is data distribution into different $\mathrm{K}$ groups with similar data and the same for the dissimilar. This difference is defined based on distance measurement criteria. Compared to grouping, clustering is an unsupervised grouping process, where the groups are not predefined. Clustering is an indirect data mining operation [42].

In most data mining methods, like the decision trees and neural networks, the process begins with an educational set through which it is sought to devise a model that would make the data in segments and then predicts the appropriate set for a new data. On the contrary, in the clustering, there exist no initial group and the variables are not divided into two independent and dependent groups. In clustering, the focus is on groups of objects that are similar, which when 
discovered, their behaviors can be identified better, indicating better decision making [43].

In hierarchical clustering, clusters are expressed as a tree named dendrogram. These algorithms can be in up-down divider or bottom-up adder format, where, the divider must specify which two clusters are divided into two parts and how is this done, while in the additive, the algorithm begins from one cluster and then, the two clusters merge to obtain a make a throughout cluster [44].

\section{Methodology}

Project success depends on the delivery of the service and product, creating value for the customer while adapting to the changing world of modern business. Next to the economic approach, the sustainable development that covers the project revenue and profitability, attention must be directed on environmental consequences, resource protection, and the project performance in the social dimension. In this study, a framework is provided for analyzing the agility factors in project-oriented with respect to sustainability approach in large QFD projects. Then, the proposed method is solved as a case study as a sample for large projects. The applied algorithm and description of the phases is illustrated in Figure 1.

The research method is explained separately for each phase as follows:

Phase 1: identifying the key factors of success in project management, sustainability, and agility in projectoriented organizations

This phase is accomplished in three steps to identify project management critical success factors, agility factors in project-oriented organizations, and sustainability factors.

Step 1: a review made on the research literature to identify project management critical success factors. In this step, project management critical success factors are identified through reviewing the research literature, and then, final indices are selected by interviewing the experts.

Step 2: a review made on the research literature to identify agility factors in project orientation organizations.

In this step, agility factors in project-oriented organizations are identified through reviewing the research literature, and then, final indices are selected by interviewing the experts.

Step 3: a review on the research literature to identify sustainability factors.

In this step, sustainability factors are identified through reviewing the research literature, and then, final indices are selected by interviewing the experts.

Phase 2: measuring the critical success factors in project management, sustainability, and agility in projectoriented organizations
In this phase, project management critical success factors' weights, agility factors' weight, and sustainability factors' weight are determined based on experts' point of view.

Step 4: measuring the indices in each approach from the experts' perspective, through academic experts' perspective.

(1) Project management critical success factors' weight determination: each factor's weight is determined based on project management and academic experts' point of view and using the questionnaire that is prepared based on Likert scale.

(2) Agility factors' in weight determination: each factor's weight is determined based on project management and academic experts' point of view and using the questionnaire that is prepared based on Likert scale.

(3) Sustainability factors' weight determination: each factor's weight is determined based on project management and academic experts' point of view and using the questionnaire that is prepared based on Likert scale.

Step 5: measuring the indices in each approach from the experts' perspective, based on the organizational experts' perspective.

(1) Determining the importance weight of critical success factors in project management field: the weight of each factor is determined based on Isfahan $\mathrm{Mu}-$ nicipality project management staffs' point of view and using questionnaire that is applied Likert scale.

(2) Determining the importance weight of agility factors in project-oriented organizations: the weight of each factor is determined based on Isfahan Municipality project management staffs' point of view and using questionnaire that is applied Likert scale.

Phase 3: calculating the agility weight factors in projectoriented organizations based on the critical success factors in project management with a sustainability approach in projects by applying two-stage QFD

Step 6: calculating the sustainability factors' weights based on critical success factors in project management applying QFD

For this purpose, the house of quality matrix is applied to determine the relative importance of sustainability factors based on project management critical success factors of project management. To this end, as Table 4 shows that QFD matrix is formed to rank sustainability factors based on the project management critical success factors and to signify the relative weight of sustainability factors.

Step 7: calculating the agility factors' weight in project-oriented organizations based on balanced sustainability factors by applying QFD 


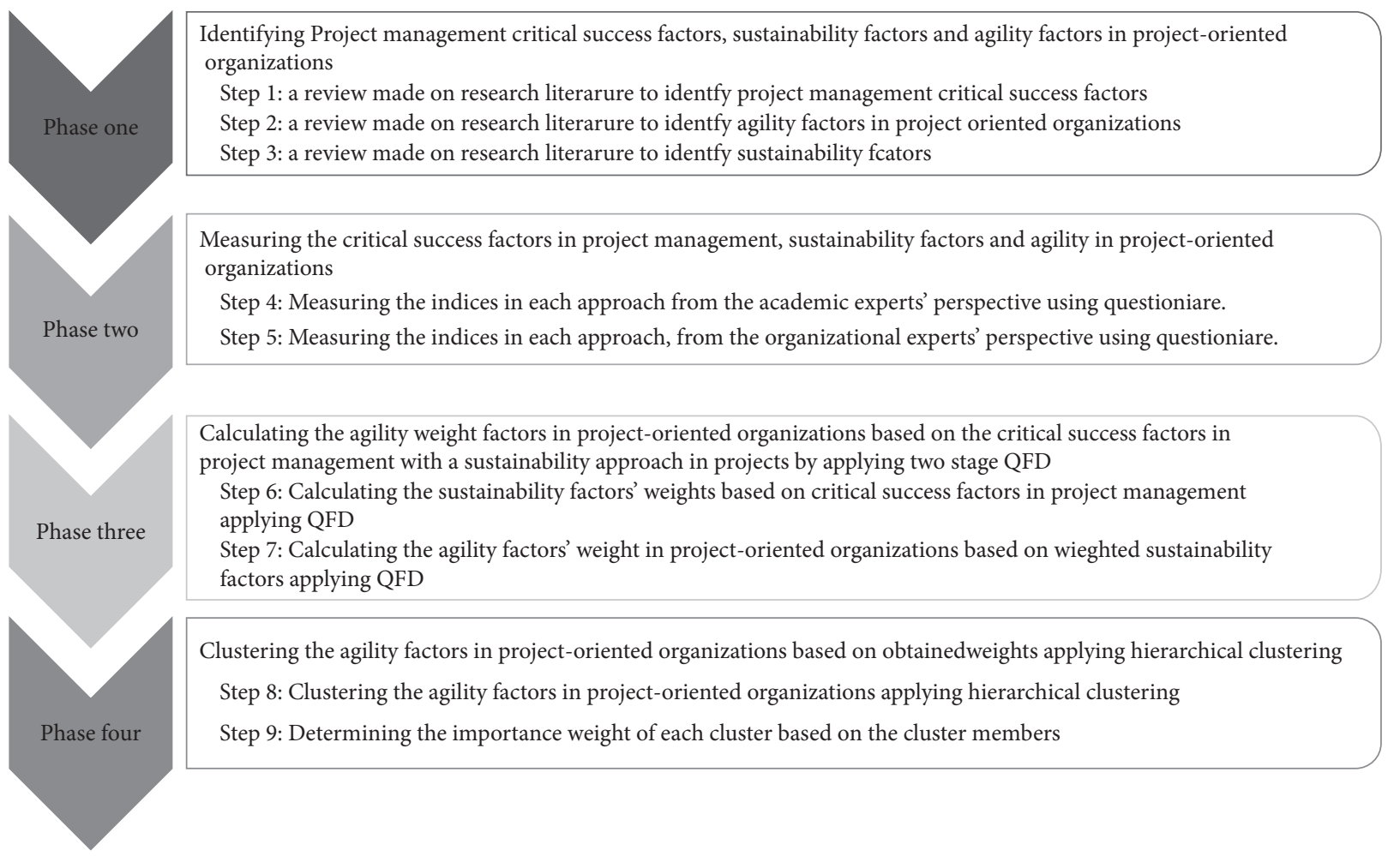

FIgURE 1: Research method.

TABLE 4: QFD matrix: PM CSFs-Sustainability factors.

\begin{tabular}{|c|c|c|}
\hline \multirow{2}{*}{ Critical success factors } & \multicolumn{2}{|c|}{ Sustainability factors } \\
\hline & Critical success indices weight & Sustainability factors \\
\hline \multirow{4}{*}{ Project management critical success factors } & $\mathrm{S}_{11 \ldots \mathrm{S} 1 \mathrm{n}}$ & C 1 \\
\hline & . & . \\
\hline & . & . \\
\hline & $\mathrm{S} n 1 \ldots \mathrm{S} n \mathrm{n}$ & $\dot{C} \mathrm{n}$ \\
\hline $\begin{array}{l}\text { Weighted summation of the sustainability } \\
\text { success factors }\end{array}$ & project management critical & $S \mathrm{cl} \ldots \mathrm{S} \mathrm{cn}$ \\
\hline
\end{tabular}

For this purpose, the house of quality matrix is applied to determine the relative importance of agility factors in project-oriented organizations based on sustainability factors. To this end, as Table 5 shows, QFD matrix is formed to rank sustainability factors based on the project management critical success factors and to signify the relative weight of sustainability factors.

Phase 4: clustering the agility factors in project-oriented organizations based on obtained weights applying hierarchical clustering

In this phase, agility factors in project-oriented organizations are clustered applying a hierarchical clustering model and based on importance weights that have been gained in second and third phase.

Step 8: clustering the agility factors in project-oriented organizations based on weight indices obtained by applying hierarchical clustering
In this step, the importance value of each cluster is determined according to the clustering results that have been gained in the previous step and based on the factor members' importance weight of each cluster. Step 9: determining the importance of the agility factors clusters in project management based on the member factors of each cluster.

In this step, the importance of each cluster is determined based on the factors that are counted as a cluster member in the previous step and then the most important cluster is signified.

\section{Implementation of the Proposed Framework in Large Projects of Isfahan Megacity Municipality}

This research has been done with the aim of clustering and analyzing large projects based on agility factors in project- 
TABle 5: QFD matrix: PM CSFs-Sustainability factors.

\begin{tabular}{lcc}
\hline $\begin{array}{l}\text { Sustainability } \\
\text { indices }\end{array}$ & $\begin{array}{c}\text { Agility indices } \\
\text { Sustainability factors } \\
\text { weight }\end{array}$ & $\begin{array}{c}\text { Agility } \\
\text { factors }\end{array}$ \\
\hline & A 11. . A 1n & C 1 \\
Sustainability factors &. & $\cdot$ \\
&. & $\cdot$ \\
$\begin{array}{l}\text { Weighted summation of the agility indices weight } \\
\text { according to sustainability indices }\end{array}$ & A s1. . A sn \\
\hline
\end{tabular}

oriented organizations and considering the sustainability attitude and applying the Quality Function Deployment. The study has been done in the period of 2018-2019 and in the city of Isfahan as a spatial range. The proposed framework has been applied in Isfahan Municipality and for the large projects.

Phase 5: identifying the key factors of project management success, sustainability, and agility in projectoriented organizations.

Step 1: reviewing the related literature and identifying the project management critical success factors

By reviewing the literature and interviewing academic experts and project management, the main factors of success in project management are identified, and the final indices are determined according to the experts' opinions (Table 6).

Step 2: reviewing the literature and identifying the agility factors in project-oriented organizations

By reviewing the related literature and interviewing academic experts and project management, agility factors in project-oriented organizations are identified, and the final indices are determined based on the opinion of experts (Table 7).

Step 3: reviewing the related literature and identifying the sustainability factors

By reviewing the research literature and interviewing academic experts and project management, the factors of sustainability are identified and the final indices are extracted according to the opinion of experts (Table 8).

Phase 6: measuring the importance of project management critical success factors, sustainability factors, and agility factors in project-oriented organizations

Step 4: this measuring consist of three approaches where a questionnaire based on project management and academic experts' opinions is devised as the instrument.

(1) Determining the project management critical success factors' importance weight in project management: through the devised questionnaire based on the Likert scale ( 1 to 5 , that is, a low importance to high importance), which has been distributed among 13 project managers and university professors in this field with 7 years of experience and published scientific articles.
(2) Determining the importance weight and agility factors in project-oriented organizations: the same procedure above is followed.

Step 5: measuring the importance weight of factors in all three approaches through the devised questionnaire based on project management experts' viewpoint in the field of opinions in Isfahan Municipality.

(1) Determining the importance weights of the project management critical success factors: it has been determined based on the project management staff viewpoints and through the questionnaire with Likert scale ( 1 to 5 , that is, low importance to 5 high importance), which has been distributed among 52 staff members.

(2) Determining the importance weight of agility factors in project-oriented organizations: based on the project staff point of view and through a questionnaire with Likert scale ( 1 to 5 , that is, a low importance to 5 high importance), which has been distributed among the employees in this field, including 52 staff. Table 9 shows the geometric mean of agility factors' weights in projectorient organizations.

Phase 7: calculating agility factors' weights in projectoriented organizations based on project management success and sustainability approach

In this phase, the agility factors' weights are calculated based on the extracted weights of sustainability factors according to the project management critical success factors, and then, agility factors' weights are calculated based on sustainability factors' weights applying QFD.

Step 6: calculating the sustainability factors' weights based on project management critical success factors by applying QFD

For this purpose, the house of quality matrix is applied to determine the relative importance of sustainability factors based on project management critical success factors. The house of quality matrix is configured to rank sustainability factors based on project management critical success factors and to determine the relative weight of sustainability factors, which are detailed in Table 10.

Step 7: calculating the agility factors' weights in relation to sustainability factors' weights in projectoriented organizations by applying QFD

The house of quality matrix is configured to rank agility factors based on stability factors and determining the relative agility weights' indices in project-oriented organizations, which are shown in Table 11. For matrix columns, agility factors are also considered in project-oriented organizations. The QFD matrix designed by the experts is completed, and its geometric mean is inserted in the matrix cells. By multiplying the stability factors' weights in each one of the columns and normalizing the 
TABLE 6: Critical success factors of project management.

\begin{tabular}{|c|c|c|}
\hline Row & Indices & The critical success factors in project management \\
\hline 1 & \multirow{6}{*}{$\begin{array}{c}\text { Project management } \\
\text { related }\end{array}$} & Leading and managing the project team \\
\hline 2 & & Applying innovative management techniques and innovative ideas [44] \\
\hline 3 & & Applying the project management standard [45] \\
\hline 4 & & Exercising strong project management leadership $[46,47]$ \\
\hline 5 & & Project management responsibility and commitment $[14,19,31]$ \\
\hline 6 & & Senior and executive management support $[14,19,31,35]$ \\
\hline 7 & \multirow{6}{*}{ Project team-related } & Employing experienced experts in the project management team $[42,46,48]$ \\
\hline 8 & & Ability to perform team work [31] \\
\hline 9 & & The expertise and skillfulness of the project management team $[44,46,48]$ \\
\hline 10 & & Appropriate reward and penalty systems $[14,19]$ \\
\hline 11 & & Self-learning teams $[44]$ \\
\hline 12 & & Confidence and consent among team members \\
\hline 13 & \multirow{3}{*}{ Project-related } & Project objectives access level \\
\hline 14 & & Safety first \\
\hline 15 & & Determining the requirements at the beginnings of the project and provide the details for each phase \\
\hline 16 & \multirow{3}{*}{ Consumer-related } & Customer participation level $[20,48]$ \\
\hline 17 & & Consumer satisfaction [44] \\
\hline 18 & & $\begin{array}{l}\text { Ability to conduct soft management for the beneficiaries in controversies and competitions therein } \\
{[20,48]}\end{array}$ \\
\hline 19 & \multirow{5}{*}{ Quality-related } & Supervision and control of the project $[14,20,48]$ \\
\hline 20 & & Transparent planned objectives and strategies $[16,44]$ \\
\hline 21 & & Contract articles' actualization rate $[19,44]$ \\
\hline 22 & & Accomplishing the agreed quality [44] \\
\hline 23 & & Orderly discourse with the beneficiaries during the project [45] \\
\hline 24 & \multirow{3}{*}{ Time management } & Conducting regular meetings between project management and the staff [44] \\
\hline 25 & & On-time project delivery management $[19,48]$ \\
\hline 26 & & Proper management of the project physical resources $[44,46]$ \\
\hline 27 & \multirow[t]{2}{*}{ Cost management } & Project conformity level with the designated budget $[18,48]$ \\
\hline 28 & & Elimination of unnecessary in project phase planning \\
\hline
\end{tabular}

TABLE 7: Agility factors in project-oriented organizations [43].

\begin{tabular}{lcc}
\hline Row & Field & Index \\
\hline 1 & Communications management project & Horizontal communications vs. hierarchical \\
2 & Communicational coherency rate in the project \\
3 & Strong and orderly project staff communication \\
4 & Providing the grounds for consultant communication with the beneficiaries \\
5 & Access to valuable data on time \\
6 & Access to classified database \\
7 & Organizational culture & Sharing knowledge and information in the project \\
8 & & Allowing project managers and staff to draw decisions \\
9 & Organizational perspective of the project management \\
10 & Decentralized decision making \\
11 & Project management transparency \\
12 & Project management & Accurate management method execution \\
13 & & Accurate management method execution level \\
14 & Applying new management method \\
15 & Applying proper project management \\
16 & Leadership through brisk managers \\
17 & Project structure to project requirements' ratio \\
18 & Accurate short-term planning \\
19 & & Proper scheduling with respect to accessible resources \\
20 & Accurate predictions of project requirements \\
21 & Simulations execution of activities \\
23 & & Project schedule modification
\end{tabular}


TABle 7: Continued.

\begin{tabular}{|c|c|c|}
\hline Row & Field & Index \\
\hline 24 & & Project risk management \\
\hline 25 & & Accurate perception of project format \\
\hline 26 & & Project budget estimation \\
\hline 27 & Project speed & Estimating project requirements in the shortest time \\
\hline 28 & & Rapid decision drawing \\
\hline 29 & & Rapid response to the client and the beneficiaries \\
\hline 30 & & Providing training in the shortest time possible \\
\hline 31 & & Implementing the simple and practical rules \\
\hline 32 & & Eliminating organization bureaucracy \\
\hline 33 & & Workforce flexibility \\
\hline 34 & Flexibility & Adaptive management \\
\hline 35 & & Managing essential changes in the project \\
\hline 36 & & Rapid response to environmental changes in the project \\
\hline 37 & & Effective response to client's inquiries \\
\hline 38 & Responsiveness & Rapid response to customer requests \\
\hline 39 & & Considering clients' expectations in the contract \\
\hline 40 & Contract management & General and specific contract conditions' transparency \\
\hline 41 & & Selecting proper contract style \\
\hline 42 & & Selecting contractor with proper criteria \\
\hline 43 & & Reading the contractor records \\
\hline 44 & Contractor management & Evaluating the contractor records \\
\hline 45 & & Establishing proper communication among contractor, consultant and client \\
\hline 46 & & Awareness of new technologies \\
\hline 47 & Technology & Providing the proper hardware \\
\hline 48 & & Applying the proper software \\
\hline 49 & & Data security level \\
\hline 50 & & Data management \\
\hline 51 & & Provide coherent information system \\
\hline 52 & & Information electronic transaction \\
\hline 53 & & Providing the means for project agility \\
\hline 54 & & Providing motivation in the respectful teams \\
\hline 55 & & Providing team work \\
\hline 56 & IT in project and human resources & On-time salary payment \\
\hline 57 & & Secure employee satisfaction \\
\hline 58 & & Employing skilled staff \\
\hline 59 & & Employing multifunctional staff \\
\hline 60 & & Prioritizing continuous training of the team members \\
\hline 61 & & Promoting team objective orientation \\
\hline 62 & & Proper task assignment \\
\hline 63 & & Respecting customers' ideas \\
\hline 64 & Focus on consumer & Beneficiaries involvement in contract negotiations \\
\hline 65 & & Customer interests' consideration \\
\hline
\end{tabular}

TABle 8: Stability features of each dimension.

\begin{tabular}{|c|c|c|}
\hline Row & Dimension & Stability features of each dimension \\
\hline 1 & & Available sufficient sustainable financial sources $[24,49,50]$ \\
\hline 2 & & Savings in costs and proper manpower use [22] \\
\hline 3 & & Proper resource and local facilities application in the project [51] \\
\hline 4 & & Improving socioeconomic status $[51,52]$ \\
\hline 5 & & Increasing efficiency and manipulation [52] \\
\hline 6 & & Reducing project time \\
\hline 7 & Economic & Reducing indirect costs (annual operational costs and maintenance costs) [22] \\
\hline 8 & & Promoting infrastructure quality [53] \\
\hline 9 & & Savings in energy consumption $[24,52]$ \\
\hline 10 & & The project's economic efficiency $[24,47,49-51]$ \\
\hline 11 & & Project sustainable revenues $[24,49,50,52,54]$ \\
\hline 12 & & Reducing construction and facilities installation costs [22] \\
\hline
\end{tabular}


TABle 8: Continued.

\begin{tabular}{|c|c|c|}
\hline Row & Dimension & Stability features of each dimension \\
\hline 13 & & Providing job for the local manpower [52] \\
\hline 14 & & The importance of the sociopolitical nature of the project [49] \\
\hline 15 & & Promoting business ethics and prevent corruption $[50,53,55]$ \\
\hline 16 & & Improving social health $[22,49,52]$ \\
\hline 17 & & Supporting social security [49] \\
\hline 18 & Social & Accepting the social nature of project [54] \\
\hline 19 & & Contributing to justice in social setting $[24,50]$ \\
\hline 20 & & Consumer cooperation rate $[52]$ \\
\hline 21 & & Private sector investment rate $[25]$ \\
\hline 22 & & Consumer requirements meeting [52] \\
\hline 23 & & Finished goods/service safety rate $[50,51]$ \\
\hline 24 & & Reducing and managing the environmental reduction [49] \\
\hline 25 & & Adopting project with the local climatic conditions [52] \\
\hline 26 & & Renewal resources efficiency rate [52] \\
\hline 27 & & Preventing water, air, social and noise pollution $[24,25]$ \\
\hline 28 & & Improving environmental hygiene $[25,52]$ \\
\hline 29 & Environmental & Reducing nonrenewable resource consumption $[25,52]$ \\
\hline 30 & & Following green provision $[22,24,51]$ \\
\hline 31 & & Applying new environment friendly technologies and products [24] \\
\hline 32 & & Being aware of environmental effects of the project $[22,49]$ \\
\hline 33 & & Industrial management and ability to run recyclable industry $[24,25,50]$ \\
\hline
\end{tabular}

TABLE 9: Geometric mean of agility factors' weights in project-orient organizations.

\begin{tabular}{lcc}
\hline Every agility feature in project-oriented organization & & Weight \\
& Experts & Municipality staff \\
\hline Project communication management & 4.023 & 3.926 \\
Organizational culture & 3.782 & 3.908 \\
Project management & 4.002 & 3.953 \\
Project scheduling and control & 4.016 & 4.052 \\
Project speed & 3.984 & 4.089 \\
Flexibility & 3.939 & 3.943 \\
Response & 3.712 & 3.940 \\
Coherent management & 3.847 & 3.995 \\
Contractor/supplier management & 3.996 & 4.005 \\
Technology & 4.198 & 3.807 \\
IT in project & 3.974 & 4.045 \\
Project human resources & 4.075 & 4.099 \\
\hline
\end{tabular}

results, the agility factors in the project-oriented organizations are obtained.

Phase 8: clustering of agility factors in project-oriented organizations based on weighted factors obtained from three weighting attitudes

In this phase, the agility factors in project-oriented organizations are clustered based on the weights obtained from the second phase, according to the project management and academic experts' opinions and the weight obtained from the third phase by solving the QFD matrices. Table 12 shows the weights of agility factors based on the three considered attitudes.
Based on the weights obtained in the second phase and the results and the weights obtained from the third phase by solving QFD matrices, the analysis details for agility factors in project-oriented organizations are tabulated in Table 12.

Phase 9: clustering the agility factors in project-oriented organizations based on weight indices obtained from three weight approaches

In this phase, the agility factors in project-oriented organizations are clustered based on the weights obtained from the second phase based as to the project managements' point of views and academic experts and the weight obtained from the third phase by solving 


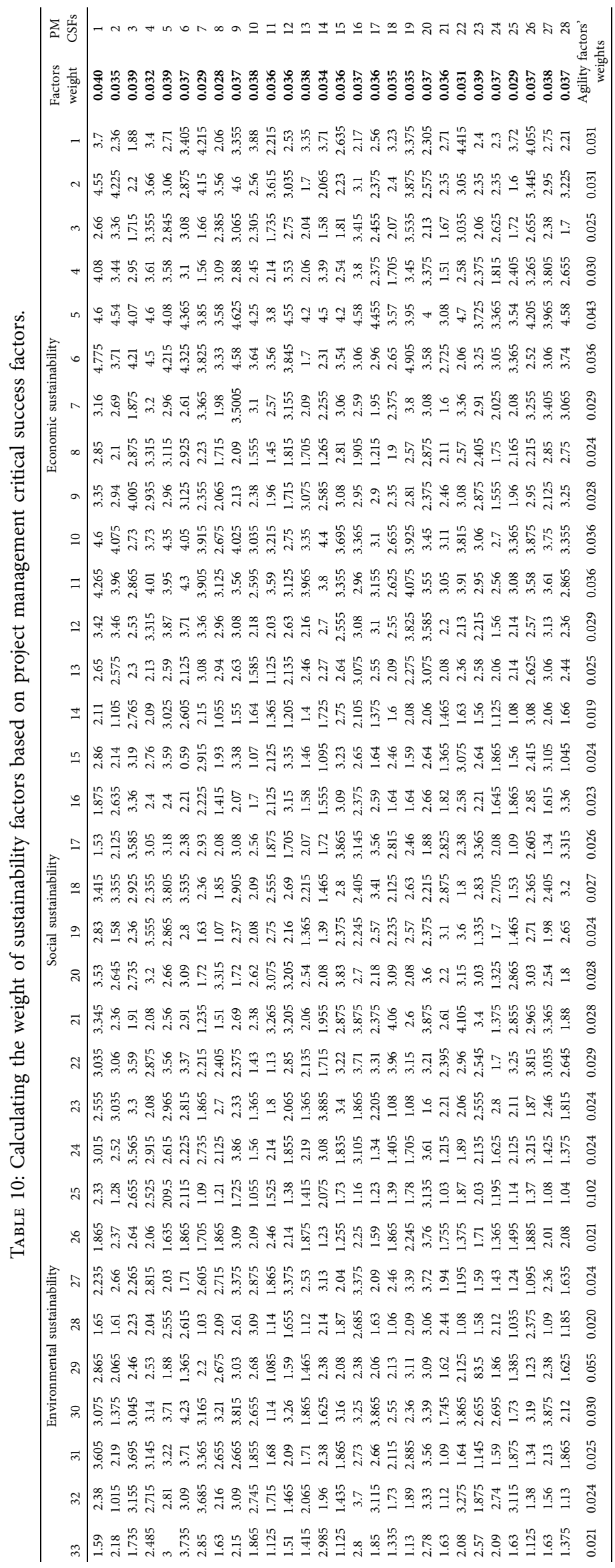


TABLE 11: Calculating the weight of agility factors in project-oriented organizations in relation to sustainability factors' weights applying QFD.

\begin{tabular}{|c|c|c|c|c|c|c|c|c|c|c|c|c|c|c|}
\hline \multicolumn{14}{|c|}{ Agility factors in project-oriented organizations } & \multirow{2}{*}{ Sustainability factors } \\
\hline 13 & 12 & 11 & 10 & 9 & 8 & 7 & 6 & 5 & 4 & 3 & 2 & 1 & Factors weight & \\
\hline 2.070 & 2.125 & 2.625 & 4.560 & 3.590 & 4.200 & 3.560 & 3.800 & 4.125 & 4.020 & 4.465 & 2.750 & 3.000 & 0.031 & 1 \\
\hline 3.400 & 4.375 & 3.090 & 4.465 & 3.635 & 3.125 & 4.100 & 3.160 & 3.965 & 4.590 & 4.410 & 3.915 & 2.580 & 0.031 & 2 \\
\hline 3.135 & 3.930 & 3.125 & 2.375 & 2.625 & 2.865 & 3.365 & 2.860 & 3.725 & 3.590 & 4.200 & 3.215 & 3.365 & 0.025 & 3 \\
\hline 3.310 & 3.460 & 2.215 & 2.570 & 2.625 & 2.640 & 2.125 & 2.300 & 1.570 & 2.625 & 4.160 & 3.580 & 3.085 & 0.030 & 4 \\
\hline 2.660 & 3.070 & 3.450 & 3.950 & 3.165 & 3.540 & 4.000 & 2.715 & 3.800 & 4.640 & 4.210 & 3.215 & 3.625 & 0.043 & 5 \\
\hline 2.460 & 3.350 & 3.275 & 4.060 & 3.615 & 4.125 & 3.610 & 3.115 & 4.060 & 4.210 & 4.110 & 2.125 & 3.540 & 0.036 & 6 \\
\hline 2.570 & 2.625 & 3.835 & 4.125 & 3.360 & 3.635 & 3.625 & 2.360 & 3.440 & 3.625 & 3.965 & 2.875 & 3.390 & 0.029 & 7 \\
\hline 2.060 & 2.580 & 1.610 & 3.815 & 3.060 & 2.440 & 1.375 & 2.570 & 1.510 & 3.075 & 4.625 & 3.610 & 2.850 & 0.024 & 8 \\
\hline 2.160 & 2.625 & 2.375 & 4.475 & 1.640 & 2.660 & 2.590 & 2.080 & 2.610 & 3.000 & 4.055 & 2.580 & 3.580 & 0.028 & 9 \\
\hline 2.570 & 2.365 & 3.580 & 3.500 & 2.375 & 3.250 & 2.590 & 2.160 & 2.365 & 3.610 & 4.140 & 2.865 & 2.360 & 0.036 & 10 \\
\hline 3.085 & 2.125 & 2.885 & 2.625 & 3.580 & 2.875 & 2.000 & 2.600 & 1.875 & 3.570 & 4.090 & 3.840 & 3.385 & 0.036 & 11 \\
\hline 2.030 & 2.570 & 2.125 & 4.060 & 2.070 & 2.140 & 2.625 & 2.965 & 2.525 & 3.580 & 4.125 & 2.610 & 2.165 & 0.029 & 12 \\
\hline 2.375 & 3.110 & 1.815 & 1.950 & 3.165 & 3.100 & 1.875 & 2.100 & 1.125 & 2.590 & 4.000 & 2.950 & 3.880 & 0.025 & 13 \\
\hline 1.100 & 3.075 & 3.250 & 2.500 & 3.060 & 2.510 & 1.900 & 1.900 & 1.140 & 2.975 & 2.360 & 2.125 & 3.350 & 0.019 & 14 \\
\hline 1.415 & 4.080 & 2.450 & 2.125 & 3.850 & 2.340 & 1.800 & 2.200 & 1.615 & 3.865 & 4.080 & 3.885 & 2.730 & 0.024 & 15 \\
\hline 3.115 & 4.600 & 3.150 & 1.640 & 3.100 & 2.900 & 4.200 & 3.000 & 2.195 & 4.105 & 3.800 & 4.125 & 3.575 & 0.023 & 16 \\
\hline 2.340 & 4.200 & 2.800 & 1.560 & 3.160 & 4.365 & 3.600 & 2.555 & 1.580 & 3.300 & 2.665 & 4.210 & 2.700 & 0.026 & 17 \\
\hline 3.265 & 2.580 & 3.530 & 2.375 & 2.940 & 3.365 & 3.760 & 2.375 & 1.860 & 4.080 & 4.410 & 3.750 & 3.405 & 0.027 & 18 \\
\hline 2.440 & 3.365 & 3.865 & 2.065 & 3.080 & 4.400 & 3.950 & 1.900 & 1.465 & 2.840 & 3.125 & 3.085 & 2.355 & 0.024 & 19 \\
\hline 4.165 & 4.625 & 4.160 & 1.530 & 1.915 & 1.300 & 2.855 & 3.095 & 2.030 & 2.950 & 3.275 & 3.815 & 4.165 & 0.028 & 20 \\
\hline 3.350 & 3.925 & 3.625 & 1.865 & 4.605 & 3.830 & 3.310 & 3.100 & 2.530 & 2.850 & 2.865 & 4.080 & 4.025 & 0.028 & 21 \\
\hline 4.150 & 2.625 & 2.365 & 3.550 & 2.580 & 3.570 & 2.650 & 2.350 & 1.600 & 3.055 & 3.910 & 2.960 & 2.565 & 0.029 & 22 \\
\hline 4.500 & 4.150 & 3.950 & 4.100 & 2.460 & 3.100 & 2.375 & 3.075 & 2.190 & 3.200 & 2.735 & 3.840 & 3.140 & 0.024 & 23 \\
\hline 3.250 & 3.410 & 3.400 & 3.805 & 3.065 & 2.400 & 1.300 & 2.070 & 1.365 & 3.000 & 2.925 & 4.150 & 2.815 & 0.024 & 24 \\
\hline 3.090 & 2.090 & 3.725 & 3.175 & 1.645 & 2.850 & 2.055 & 3.375 & 1.575 & 2.750 & 3.250 & 2.210 & 1.850 & 0.102 & 25 \\
\hline 2.355 & 3.375 & 3.365 & 4.025 & 2.725 & 2.360 & 1.375 & 2.080 & 1.640 & 2.355 & 2.665 & 3.825 & 2.460 & 0.021 & 26 \\
\hline 2.460 & 3.665 & 2.570 & 3.960 & 3.365 & 1.950 & 1.225 & 2.060 & 1.660 & 1.955 & 2.360 & 3.375 & 1.805 & 0.024 & 27 \\
\hline 2.885 & 3.960 & 2.175 & 3.580 & 2.960 & 2.220 & 1.500 & 2.225 & 1.375 & 2.085 & 2.460 & 3.965 & 2.875 & 0.020 & 28 \\
\hline 2.140 & 1.850 & 2.135 & 4.350 & 3.035 & 1.805 & 1.975 & 2.125 & 1.815 & 3.400 & 3.035 & 4.590 & 2.965 & 0.055 & 29 \\
\hline 2.625 & 4.275 & 3.825 & 2.950 & 3.725 & 3.385 & 2.080 & 2.425 & 1.955 & 2.955 & 3.350 & 4.625 & 3.105 & 0.030 & 30 \\
\hline 3.165 & 2.640 & 3.620 & 4.265 & 3.115 & 2.225 & 2.500 & 1.900 & 2.000 & 3.100 & 3.580 & 3.905 & 3.580 & 0.025 & 31 \\
\hline 2.465 & 2.480 & 3.440 & 3.075 & 2.960 & 3.810 & 2.000 & 2.210 & 1.700 & 2.655 & 3.365 & 3.400 & 3.750 & 0.024 & 32 \\
\hline 2.040 & 3.365 & 2.965 & 4.090 & 3.515 & 3.115 & 1.875 & 1.850 & 1.660 & 2.500 & 2.095 & 3.780 & 2.350 & 0.021 & 33 \\
\hline 2.764 & 3.075 & 3.081 & 3.297 & 2.916 & 2.979 & 2.608 & 2.591 & 2.205 & 3.270 & 3.575 & 3.366 & 2.967 & & \\
\hline 0.071 & 0.079 & 0.080 & 0.085 & 0.075 & 0.077 & 0.067 & 0.067 & 0.057 & 0.085 & 0.092 & 0.087 & 0.077 & Agility & actors' weight \\
\hline
\end{tabular}

TABLE 12: Importance weights of the agility factors' in project-oriented organizations through the three attitudes.

\begin{tabular}{lcccc}
\hline $\begin{array}{l}\text { Agility in project-oriented } \\
\text { organizations }\end{array}$ & $\begin{array}{c}\text { Agility weight } \\
\text { importance } \\
\text { (average) }\end{array}$ & $\begin{array}{c}\text { Agility weight } \\
\text { importance } \\
\text { (experts) }\end{array}$ & $\begin{array}{c}\text { Agility weight importance } \\
\text { (municipality staff) }\end{array}$ & $\begin{array}{c}\text { Agility weight importance } \\
\text { (sustainability approach) }\end{array}$ \\
\hline Project communication & 0.0733 & 0.0768 & 0.0764 & 0.0769 \\
management & 0.0750 & 0.0751 & 0.0760 & 0.0739 \\
Project culture & 0.0864 & 0.1074 & 0.0769 & 0.0782 \\
Project management & 0.0830 & 0.0926 & 0.0788 & 0.0785 \\
Project scheduling & 0.0757 & 0.070 & 0.0795 & 0.0799 \\
Project speed & 0.0739 & 0.0683 & 0.0767 & 0.077 \\
Flexibility & 0.0736 & 0.0716 & 0.0766 & 0.0726 \\
Response & 0.1658 & 0.0780 & 0.0777 & 0.0725 \\
Coherent management & 0.0762 & 0.0726 & 0.0779 & 0.0781 \\
Contractor's management & 0.0820 & 0.0908 & 0.074 & 0.0821 \\
Technology & 0.0749 & 0.0686 & 0.0787 & 0.0777 \\
Project IT & 0.0756 & 0.0708 & 0.0797 & 0.0793 \\
Human resources & 0.0678 & 0.0619 & 0.0712 & 0.0708 \\
Focusing on consumer & & & \\
\hline
\end{tabular}




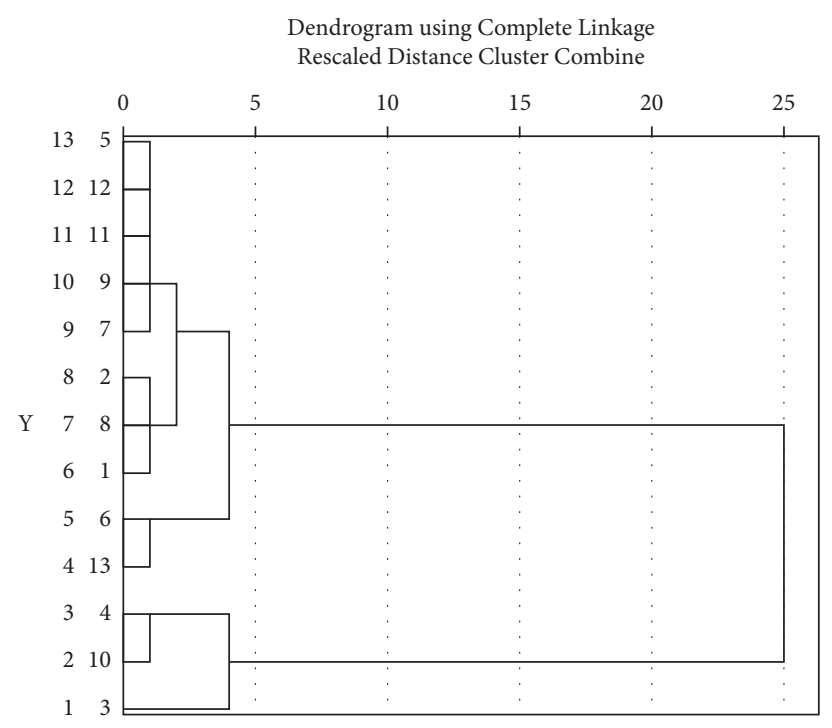

FIgURE 2: Dendrogram from hierarchical clustering.

TABLE 13: Results of clustering and the manner of agility factors placement.

\begin{tabular}{lcc}
\hline Cluster \# & Agility in project-oriented organizations & Factor \# \\
\hline 1 & Project communication management & 1 \\
1 & Project culture & 2 \\
2 & Project management & 3 \\
3 & Project scheduling & 4 \\
4 & Project speed & 5 \\
5 & Flexibility & 6 \\
4 & Response & 7 \\
1 & Coherent management & 8 \\
4 & Contractor's management & 9 \\
3 & Technology & 10 \\
4 & Project IT & 11 \\
4 & Human resources & 12 \\
5 & Focusing on consumer & 13 \\
\hline
\end{tabular}

TABLE 14: The agility clusters' importance in project-oriented organizations.

\begin{tabular}{|c|c|c|c|c|c|}
\hline & Cluster 1 & Cluster 2 & Cluster 3 & Cluster 4 & Cluster 5 \\
\hline \multirow{4}{*}{ Clusters' members } & \multirow{4}{*}{$\begin{array}{l}\text { (1) Communication } \\
\text { management in project } \\
\text { (2) Organizational } \\
\text { culture } \\
\text { (3) Contracts } \\
\text { management }\end{array}$} & \multirow{4}{*}{$\begin{array}{l}\text { (1) Project } \\
\text { management }\end{array}$} & $\begin{array}{l}\text { (1) Project scheduling and } \\
\text { control }\end{array}$ & \multirow{4}{*}{$\begin{array}{l}\text { (1) Project } \\
\text { speed }\end{array}$} & (1) Flexibility \\
\hline & & & (2) Responsiveness & & \multirow{3}{*}{$\begin{array}{l}\text { (2) Focus on } \\
\text { consumers }\end{array}$} \\
\hline & & & (3) Contractors & & \\
\hline & & & $\begin{array}{l}\text { management } \\
\text { (4) IT IN PROJECT } \\
\text { (5) Human resources }\end{array}$ & & \\
\hline $\begin{array}{l}\text { Cluster's importance } \\
\text { weight }\end{array}$ & 0.0987 & 0.0864 & 0.0825 & 0.0753 & 0.0708 \\
\hline
\end{tabular}

QFD matrices, and therefore, they clustered through a hierarchical model.

Step 8: clustering the agility factors in project-oriented organizations based on weight indices obtained from the three approaches
At this stage, the agility factors are clustered through the hierarchical clustering method. The yield dendrogram is shown in Figure 2. Accordingly, considering the similarity coefficient is ${ }^{>} 95 \%$, agility factors in project-oriented organizations are located in five 
clusters, and the clustering details therein are tabulated in Table 13.

Step 9: determining the importance of the agility factors' clusters in project management based on the member factor of each cluster.

In this step, based on both the results of the previous step and the weight of clusters' factors, the importance of each cluster is determined, and each cluster's rank is determined according to their importance value. As observed in Table 13, after determining the average importance weight of the agility factors' in project-oriented organizations, for the agility factors that they are members of clusters, the weighted mean of each factor is calculated to obtain the importance weight of cluster. The cluster with the highest weight is placed at the top of the clusters' importance (Table 14).

As observed in this table, clusters one, two, and three are ranked in the first to third as to their importance, respectively.

\section{Conclusion}

To manage and execute a project, in project-oriented organizations, concentrating on the required infrastructures and providing the project management critical success factors, together in addition of considering the importance of environmental resources and social effects of the project and also the profitability and economic aspect which puts the organization in line with appropriate development, as to form a successful project management at macro and microlevels is of essence. By doing so, a big step is taken towards accountability and customer satisfaction due to project implementation, by considering sustainability indices. Therefore, a framework is introduced for clustering and analysis of big projects based on agility factors in project-oriented organizations with a sustainability approach, by applying quality functionality development tool. The proposed framework has been implemented and solved in Isfahan Metropolitan Municipality. For this purpose, in phase one, first, the project management critical success factors and, next, the agility factors and in project-oriented organizations and sustainability factors are identified. In phase two, the importance of the project management critical success factors and, next, agility factors in project-oriented organizations are measured from the perspective of large project managers in Isfahan Municipality and university experts. In phase three, the weights of agility factors in project-oriented organizations are calculated based on the weighted factors of sustainability according to the critical success factors in the large projects by applying quality function deployment. In phase four, the agility factors in project-oriented organizations are clustered based on the previously obtained weights. Next to guiding project managers to focus on the major success factors in project management and providing sustainability factors as to the big projects' and activities' impact on the field of environmental resources, social resources, and economic aspects, through focusing on agility factors, they can obtain the desired customer satisfaction level, timely delivery, and desired quality as the major concerns. As observed in Table 14, the first cluster, which includes project communication management, organizational culture, and contract management, is the most important at (0.0987) weight rate. Because these weights are based on sustainability and project management critical success factors, focusing on the important cluster is highly contributive in organizations' success in project management next to the principles of sustainable development and establishing the principles of agility.

\section{Research Constraints}

The measures taken in this study, despite the accuracy of the presented framework and application of the applied factors, can be improved by removing any of the constraints therein. Depending on the subject organization, the projects and conditions, addition, elimination, and replacing the applied factors can be contributive in closer insight therein. The findings are implemented on Isfahan Municipality's big projects. To be focused on the paramount cluster helps the organization to be successful in project management in line with setting the principles of the sustainable development and by stablising the principles of the organizational agility in project-oriented organizations.

\section{Suggestions for Future Studies}

Assessing the sensitivity analysis of indices and the effect on the clusters' ordering can lead to different and accurate results in the performance of the organization. Moreover, evaluating the performance of projects through the evaluation and performance analysis methods, subject to each approach in addition to the presence of combined approaches, can be effective in improving efficiency. The effect of each one of these approaches on project cost, time, and quality must be considered in project performance assessment.

\section{Data Availability}

The research data are available within the article (Tables and Figures) in detail.

\section{Conflicts of Interest}

The authors declare that they have no conflicts of interest.

\section{References}

[1] G. M. Nicholls, N. A. Lewis, and T. Eschenbach, "Determining when simplified agile project management is right for small teams," Engineering Management Journal, vol. 27, no. 1, pp. 3-10, 2015.

[2] C. M. Felipe, J. L. Roldán, and A. L. Leal-Rodríguez, "An explanatory and predictive model for organizational agility," Journal of Business Research, vol. 69, no. 10, pp. 4624-4631, 2016.

[3] A. Stare, "Agile project management in product development projects," Procedia - Social and Behavioral Sciences, vol. 119, pp. 295-304, 2014.

[4] L. Fonseca, A. Amaral, and J. Oliveira, "Quality 4.0: the EFQM 2020 model and industry 4.0 relationships and implications," Sustainability, vol. 13, no. 6, Article ID 3107, 2021. 
[5] B. A. Abdulrahman and F. A. N. Abdallah, "Critical success factors (CSFS) in project management: critical review of secondary data," International Journal of Scientific and Engineering Research, vol. 5, no. 6, pp. 325-331, 2014.

[6] V. Obradović, M. Todorović, and S. Bushuyev, "Sustainability and agility in project management: contradictory or complementary?" in Proceedings of the Conference on Computer Science and Information Technologies, pp. 522-532, Lviv, Ukraine, September 2018.

[7] C. R. Carter and D. S. Rogers, "A framework of sustainable supply chain management: moving toward new theory," International Journal of Physical Distribution \& Logistics Management, vol. 38, 2008.

[8] E. Gończ, U. Skirke, H. Kleizen, and M. Barber, "Increasing the rate of sustainable change: a call for a redefinition of the concept and the model for its implementation," Journal of Cleaner Production, vol. 15, no. 6, pp. 525-537, 2007.

[9] J. van den Brink and S. Gilbert, "Taking responsibility: the integration of sustainability and project management," $\mathrm{HU}$ University of Applied Sciences Utrecht, Utrecht, Netherlands, 2011.

[10] M.-M. Nahod and M. V. M. Radujković, "The impact of ICB 3.0 competences on project management success," Procedia-Social and Behavioral Sciences, vol. 74, pp. 244-254, 2013.

[11] A. Brent and C. Labuschagne, "Social indicators for sustainable project and technology life cycle management in the process industry $(13 \mathrm{pp}+4)$," International Journal of Life Cycle Assessment, vol. 11, no. 1, pp. 3-15, 2006.

[12] A. I. Gaziulusoy, "A critical review of approaches available for design and innovation teams through the perspective of sustainability science and system innovation theories," Journal of Cleaner Production, vol. 107, pp. 366-377, 2015.

[13] M. E. McCullins, Sustainability and Project Management, Athabasca University-Centre for Innovative Management, Alberta, Canada, 2007.

[14] Z. Alias, E. M. A. Zawawi, K. Yusof, and N. M. Aris, "Determining critical success factors of project management practice: a conceptual framework," Procedia - Social and Behavioral Sciences, vol. 153, pp. 61-69, 2014.

[15] A. A. Ahmadabadi and G. Heravi, "The effect of critical success factors on project success in Public-Private Partnership projects: a case study of highway projects in Iran," Transport Policy, vol. 73, pp. 152-161, 2019.

[16] T. P. Filgueira de Melo Moura, "Critical success factors for project management support information systems: SEBRAE/ RN Case," Rebrae, vol. 9, no. 1, pp. 8-25, 2016.

[17] M. Orouji, "Critical success factors in project management," Journal of Project Management, vol. 1, no. 1, pp. 35-40, 2016.

[18] F. Costantino, G. Di Gravio, and F. Nonino, "Project selection in project portfolio management: an artificial neural network model based on critical success factors," International Journal of Project Management, vol. 33, no. 8, pp. 1744-1754, 2015.

[19] S. Naoum, D. Fong, and G. Walker, "Critical success factors of project management," in Proceedings of the International Symposium on Globalization and Construction, pp. 827-838, Bangkok, Thailand, November 2004.

[20] C. H. Thi and F. W. Swierczek, "Critical success factors in project management: implication from Vietnam," Asia Pacific Business Review, vol. 16, no. 4, pp. 567-589, 2010.

[21] R. Kiani Mavi and C. Standing, "Critical success factors of sustainable project management in construction: a fuzzy DEMATEL-ANP approach," Journal of Cleaner Production, vol. 194, pp. 751-765, 2018.
[22] N. Dobrovolskienė and R. Tamošiūnienè, "An index to measure sustainability of a business project in the construction industry: Lithuanian case," Sustainability, vol. 8, pp. 14-1, 2016.

[23] M. L. Martens and M. M. Carvalho, "Key factors of sustainability in project management context: a survey exploring the project managers' perspective," International Journal of Project Management, vol. 35, no. 6, pp. 1084-1102, 2017.

[24] H. Daneshpour, "Integrating sustainability into management of project," International Journal of Environment and Sustainable Development, vol. 6, no. 4, pp. 321-325, 2015.

[25] A. Amiril, A. H. Nawawi, R. Takim, and S. N. F. A. Latif, "Transportation infrastructure project sustainability factors and performance," Procedia-Social and Behavioral Sciences, vol. 153, pp. 90-98, 2014.

[26] A. J. G. Silvius and R. Schipper, "A maturity model for integrating sustainability in projects and project management," in Proceedings of the 24th World Congress of the International Project Management Association (IPMA), Istanbul, Turkey, October 2010.

[27] R. Procter, M. Rouncefield, M. Poschen, Y. Lin, and A. Voss, "Agile project management: a case study of a virtual research environment development project," Computer Supported Cooperative Work, vol. 20, no. 3, pp. 197-225, 2011.

[28] D. J. Fernandez and J. D. Fernandez, "Agile project management-agilism versus traditional approaches," Journal of Computer Information Systems, vol. 49, no. 2, pp. 10-17, 2008.

[29] Q. Chen, G. Reichard, and Y. Beliveau, "Interface management-a facilitator of lean construction and agile project management," International Group for Lean Construction, vol. 1, no. 1, pp. 57-66, 2007.

[30] B. De Reyck, "Effective project planning: making the most of project planning tools," Production and Inventory Management Journal, vol. 46, pp. 10-2, 2010.

[31] A. Shahin and M. Jamshidian, "Critical success factors in project management: a comprehensive review," in Proceedings of the 1st International Project Management Conference, pp. 1-14, Arlington, VA, USA, November 2006.

[32] A. Munns and B. Bjeirmi, "The role of project management in achieving project success," International Journal of Project Management, vol. 14, no. 2, pp. 81-87, 1996.

[33] T. Bergmann and W. Karwowski, "Agile project management and project success: a literature review," in Proceedings of the 2018 International Conference on Applied Human Factors and Ergonomics, pp. 405-414, Orlando, FL, USA, July 2018.

[34] M. Kavacık, S. Zafer, Y. Ali, and D. Karaman, "Sustainable development in aviation industry and the case of Turkish airlines," Journal of Animal and Veterinary Advances, vol. 9, no. 3, pp. 547-550, 2012.

[35] L. M. Fonseca, J. P. Domingues, and A. M. Dima, "Mapping the sustainable development goals relationships," Sustainability, vol. 12, no. 8, Article ID 3359, 2020.

[36] L. M. Fonseca and V. M. Lima, "Countries three wise men: sustainability, innovation, and competitiveness," Journal of Industrial Engineering and Management, vol. 8, no. 4, pp. 1288-1302, 2015.

[37] L.-K. Chan and M.-L. Wu, "Quality function deployment: a comprehensive review of its concepts and methods," Quality Engineering, vol. 15, no. 1, pp. 23-35, 2002.

[38] S. Kumar, H. H. Inbarani, A. T. Azar, and A. E. Hassanien, "Rough set-based meta-heuristic clustering approach for social e-learning systems," International Journal of Intelligent Engineering Informatics, vol. 3, no. 1, pp. 23-41, 2015. 
[39] Y. Akao and G. H. Mazur, "The leading edge in QFD: past, present and future," International Journal of Quality and Reliability Management, vol. 20, 2003.

[40] C.-F. Tsai, Y.-H. Hu, and Y.-H. Lu, "Customer segmentation issues and strategies for an automobile dealership with two clustering techniques," Expert Systems, vol. 32, no. 1, pp. 65-76, 2015.

[41] A. S. Shirkhorshidi, S. Aghabozorgi, T. Y. Wah, and T. Herawan, "Big data clustering: a review," in Proceedings of the 14th International Conference on Computational Science and its Applications, pp. 707-720, Guimaraes, Portugal, June 2014.

[42] G. Piatetsky-Shapiro, "The data-mining industry coming of age," IEEE Intelligent Systems, vol. 14, no. 6, pp. 32-34, 1999.

[43] T. Sajana, C. M. S. Rani, and K. V. Narayana, "A survey on clustering techniques for big data mining," Indian journal of Science and Technology, vol. 9, no. 3, pp. 1-12, 2016.

[44] S. Banihashemi, M. R. Hosseini, H. Golizadeh, and S. Sankaran, "Critical success factors (CSFs) for integration of sustainability into construction project management practices in developing countries," International Journal of Project Management, vol. 35, no. 6, pp. 1103-1119, 2017.

[45] D. F. Ofori, "Project management practices and critical success factors-A developing country perspective," International Journal of Business and Management, vol. 8, no. 21, 2013.

[46] H. Abou-Hafs and B. Hassan, "Project Management Performance: The Success Factors of Project Management for Events-Case of the Wedding Projects in Marrakech, Morocco," Journal of Business and Economics, vol. 4, 2013.

[47] H. Shirouyehzad, F. M. Rafiei, and E. Shahgholi, "Performance evaluation of organisational units based on key performance indicators with agility approach by using MADM, QFD; a case study in Darakar Company," International Journal of Productivity and Quality Management, vol. 17, no. 2, pp. 198-214, 2016.

[48] P. W. Ihuah, I. I. Kakulu, and D. Eaton, "A review of critical project management success factors (CPMSF) for sustainable social housing in Nigeria," International Journal of Sustainable Built Environment, vol. 3, no. 1, pp. 62-71, 2014.

[49] M. L. Martens and M. M. Carvalho, "The challenge of introducing sustainability into project management function: multiple-case studies," Journal of Cleaner Production, vol. 117, pp. 29-40, 2016.

[50] V. K. Chawla, A. K. Chanda, S. Angra, and G. R. Chawla, “The sustainable project management: a review and future possibilities," Journal of Project Management, vol. 3, no. 3, pp. 157-170, 2018.

[51] L. Shen, Y. Wu, and X. Zhang, "Key assessment indicators for the sustainability of infrastructure projects," Journal of Construction Engineering and Management, vol. 137, no. 6, pp. 441-451, 2011.

[52] A. Hesampour, M. Nikbakht, and H. Shirouyehzad, "A method for ranking, assessment and evaluation of sustainability factors in project," Journal of Modern Processes in Manufacturing and Production, vol. 5, no. 1, pp. 29-44, 2016.

[53] G. Heravi, M. Fathi, and S. Faeghi, "Evaluation of sustainability indicators of industrial buildings focused on petrochemical projects," Journal of Cleaner Production, vol. 109, pp. 92-107, 2015.

[54] M. Bennet, P. James, and L. Klinkers, Sustainable Measures: Evaluation and Reporting of Environmental and Social Performance, Greenleaf Publishing, South Yorkshire, UK, 1999.
[55] H. Maylor, "Beyond the Gantt chart: Project management moving on," European Management Journal, vol. 19, no. 1, pp. 92-100, 2001. 